The rapid growth of academic literature in the field of economics has posed serious problems for both students and teachers of the subject. The latter find it difficult to keep pace with more than a few areas of the subject so that an inevitable trend towards specialism emerges. The student quickly loses perspective as the maze of theories and models grows, particularly at a time when so much reappraisal of the established paradigms is taking place.

The aim of the 'Macmillan Studies in Economics' is to offer students, and perhaps some teachers as well, short, reasonably critical overviews of developments in selected areas of economics, particularly those in which current controversies are to be found. As far as possible the titles have been selected to form an integrated whole, although inevitably entire areas have been neglected as being unsuited to the style, format and length of the titles in the series.

In some cases the volumes are rather more like essays than surveys. In most cases, however, the aim is to survey the salient literature in a critical fashion. The level of understanding required to read the volumes varies with the complexity of the subject, but they have been generally written to suit the secondand third-year undergraduate seeking to place his reading of the detailed literature in an over-all context. They are not textbooks. Instead they seek to give the kind of perspective that might well be lost by reading longer textbooks on their own, or by reading articles in journals. In particular, they should be most suited to pre-examination revision periods. They are not intended to substitute for the essential reading and assimilation of the original works that they seek to survey and assess. 


\title{
MACMILLAN STUDIES IN ECONOMICS
}

\author{
General Editors: D. C. ROWAN and G. R. FISHER
}

Executive Editor: D. W. PEARCE

\section{Published}

R. W. Anderson: THE ECONOMICS OF CRIME

John Burton: WAGE INFLATION

Susan Charles: HOUSING ECONOMICS

Ben Fine: MARX'S 'CAPITAL'

Douglas Fisher: MONETARY POLICY

Miles Fleming: MONETARY THEORY

C. J. Hawkins: THEORY OF THE FIRM

C. J. Hawkins and D. W. Pearce: CAPITAL INVESTMENT APPRAISAL

David F. Heathfield: PRODUCTION FUNCTIONS

Dudley Jackson: POVERTY

P. N. Junankar: INVESTMENT: THEORIES AND EVIDENCE

J. E. King: LABOUR ECONOMICS

John King and Philip Regan: RELATIVE INCOME SHARES

J. A. Kregel: THE THEORY OF ECONOMIC GROWTH

J. A. Kregel: THEORY OF CAPITAL

Richard Lecomber: ECONOMIC GROWTH VERSUS THE ENVIRONMENT

George McKenzie: THE MONETARY THEORY OF INTERNATIONAL TRADE

David J. Mayston: THE IDEA OF SOCIAL CHOICE

C. A. Nash: PUbliC VERSUS PRIVATE TRANSPORT

S. K. Nath: A PERSPECTIVE OF WELFARE ECONOMICS

Anthony Peaker: ECONOMIC GROWTH IN MODERN BRITAIN

D. W. Pearce: COST-BENEFIT ANALYSIS

Maurice Peston: PUBLIC GOODS AND THE PUBLIC SECTOR

Nicholas Rau: TRADE CYCLES: THEORY AND EVIDENCE

David Robertson: INTERNATIONAL TRADE POLICY

Charles K. Rowley: ANTITRUST AND ECONOMIC EFFICIENCY

C. H. Sharp: TRANSPORT ECONOMICS

G. K. Shaw: FISCAL POLICY

R. Shone: THE PURE THEORY OF INTERNATIONAL TRADE

M. J. Stabler: AGRICULTURAL ECONOMICS AND RURAL LAND-USE

Frank J. B. Stilwell: REGIONAL ECONOMIC POLICY

A. P. Thirlwall: FINANCING ECONOMIC DEVELOPMENT

R. Kerry Turner and Clive Collis: THE ECONOMICS OF PLANNING John Vaizey: THE ECONOMICS OF EDUCATION

J. van Doorn: DISEQUILIBRIUM ECONOMICS

Peter A. Victor: ECONOMICS OF POLLUTION

Graham Walshe: INTERNATIONAL MONETARY REFORM

Michael G. Webb: PRICING POLICIES FOR PUBLIC ENTERPRISES

E. Roy Weintraub: CONFLICT AND CO-OPERATION IN ECONOMICS

E. Roy Weintraub: GENERAL EQUILIBRIUM THEORY

Adrian Ziderman: MANPOWER TRAINING: THEORY AND POLICY 


\title{
Cost-Benefit Analysis
}

\author{
D. W. PEARGE
}

Professor of Political Economy,

University of Aberdeen 
(C) D. W. Pearce 1971

All rights reserved. No part of this publication may be reproduced or transmitted, in any form or by any means, without permission.

First edition 1971

Reprinted 1973, 1977, 1978, 1981, (twice).

Published by

THE MACMILLAN PRESS LTD

London and Basingstoke

Companies and representatives

throughout the world

ISBN 978-0-333-12063-7 ISBN 978-1-349-01091-2 (eBook)

DOI 10.1007/978-1-349-01091-2

The paperback edition of this book is sold subject to the condition that it shall not, by way of trade or otherwise, be lent, re-sold, hired out, or otherwise circulated without the publisher's prior consent in any form of binding or cover other than that in which it is published and without a similar condition including this condition being imposed on the subsequent purchaser. 


\section{Contents}

Acknowledgements $\quad 6$

1 The Philosophical Foundations of Cost-Benefit 7

2 The Origins of CBA 13

3 The Welfare Foundations of CBA 17

4 Efficiency and Distribution 25

5 Decision Rules 33

6 The Social Rate of Discount 39

The STPR argument 42

The opportunity-cost argument $\quad 44$

The argument for a synthetic rate 45

7 The Valuation of Costs and Benefits 51

8 Risk and Uncertainty 59

9 A Gase Study: The Third London Airport 67

Bibliography $\quad 78$ 


\section{Acknowledgements}

This work makes no pretence at being original. I hope, however, that I have managed to draw together in a very limited space the main lines of argument concerning the nature of cost-benefit analysis, its unresolved problems and the debate over its role in decision-making. The stimulus to the work came from a longer, more detailed study by Ajit Dasgupta and myself which is referred to in the text. I am very much indebted to Tony Peaker of Southampton, to Fred Pennance of the College of Estate Management, and to Professor John Wise of Southampton for comments which prevented me from making a number of errors and forced me to clarify other points. The mysteries and falsehoods that remain are entirely mine. To my wife, who very wisely took a Continental vacation while I was writing this, I owe a very special debt of thanks. For this reprinted edition I am deeply indebted to Professor John Black of Exeter University, for a number of corrections.

D.W.P. 